УДК 343.85

DOI https://doi.org/10.32837/yuv.v0i1.1558

В. Башкатова,

кандидат юридичних наук

\title{
ДЕРЖАВНА ПОЛІТИКА У СФЕРІ ЗАПОБІГАННЯ І ПРОТИДІї КОРУПЦІї В УКРАЇНІ
}

Роль держави в регулюванні суспільних відносин $є$ незаперечною, від їі ефективної політики залежить стан належного правового забезпечення, що потребує системного підходу. Наявні проблемні питання економічної нестабільності поряд із бойовими діями на сході нашої держави, зі значною кількістю проявів корупційних правопорушень і все більшими проявами правового нігілізму в суспільстві щодо запобігання і протидії корупціі. Вирішення наявних проблем організаційного, правового та політичного характеру потребує дослідження засад правової політики держави з необхідністю розроблення науково-теоретичних положень і практичних рекомендацій.

Теоретичним i практичним питанням, пов'язаним із політикою держави у сфері запобігання й протидіі корупції та вдосконаленням вітчизняного антикорупційного законодавства, зокрема адміністративного, присвячено праці вчених у галузі адміністративного права, серед яких варто відмітити таких як Д. Гудков, В. Іванюк, О. Клок, О. Панфілов, О. Світличний, Д. Сіренко, І. Сопілко та ін.

Метою статті $€$ аналіз наявних проблем особливостей національної антикорупційної правової політики держави та розроблення науково-теоретичних положень i практичних рекомендацій удосконалення політики держави у сфері боротьби з корупцією.

Запобігання і протидія корупції передусім залежать від ефективної політики держави, від якої повною мірою залежить діяльність органів і їх посадових осіб, уповноважених забезпечити реа- лізацію національної антикорупційної правової політики держави сфері запобігання i протидії корупції. Під державною антикорупційною політикою Д. Заброда розуміє передбачений законами й підзаконними нормативно-правовими актами комплекс правових, економічних, освітніх, виховних, організаційних та інших заходів, що формуються й реалізуються органами державної влади, місцевого самоврядування та громадськістю з метою виявлення, припинення фактів корупції, усунення детермінант, що їі опосередковують, відновлення порушених прав і законних інтересів фізичних, юридичних осіб і держави [1, с. 103].

При цьому запобігання корупції в умовах суспільно-політичних трансформацій визначально розуміється як складний адміністративно-правовий процес, що формалізується нормами права, реалізується через норми права й створює соціальне середовище унеможливлення корупційних дій у сфері публічного управління. Першочергового значення набуває необхідність на законодавчому рівні закріпити цілісний механізм протидії корупції та створити систему діяльності органів публічного управління, які будуть безпосередньо реалізовувати антикорупційні заходи [2, с. 95], а саму корупцію розглядають як соціально небезпечне явище, змістом якого є система негативних поглядів, настанов і діянь службових осіб інститутів влади й управління, державних i недержавних підприємств, організацій та установ, політичних партій і громадських організацій, спрямованих на задоволення особистих, групових 


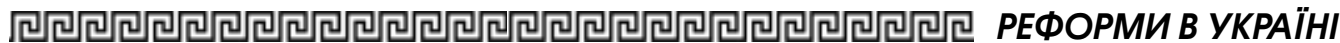

або корпоративних інтересів шляхом використання свого службового становища, усупереч інтересам суспільства та держави [3, с. 16].

У Законі України «Про засади державної антикорупційної політики в Україні (Антикорупційна стратегія) на 2014-2017 роки» від 14.10.2014 № 1699-VII [4], зазначено, що розв'язання проблеми корупції $€$ одним із пріоритетів для українського суспільства на сьогоднішньому етапі розвитку держави. За даними досліджень, наведених в Антикорупційній стратегії, саме корупція є однією з причин, що призвела до масових протестів в Украіні наприкінці 2013 року - на початку 2014 року. Згідно з результатами дослідження, 36 відсотків українців були готові вийти на вулицю, протестуючи проти корупції. За результатами проведеного дослідження громадської думки, корупція вже входила до переліку найбільших проблем населення й викликала особливе занепокоєння в 47 відсотків громадян. Українці вважають свою державу однією з найбільш корумпованих у світі.

Проте виконання завдань щодо реалізації засад державної Антикорупційної стратегії не завершено в повному обсязі. За результатами аналізу виконання зазначеної Антикорупційної стратегії та Державної програми щодо реалізації засад державної антикорупційної політики в Україні (Антикорупційної стратегіi) на 2015-2017 роки, затвердженої Постановою Кабінету Міністрів України від 29.04.2015 № 265, виконано лише дві третини передбачених заходів [5]. Частина заходів виконана не в повному обсязі. Причинами невиконання заходів, визначених засадами державної антикорупційної політики в Україні, є тривале становлення нових антикорупційних інститутів, недоліки законодавства 3 питань запобігання корупції та його застосування, відсутність належного механізму моніторингу й оцінювання виконання зазначеної Антикорупційної стратегії та високий рівень толерантності суспільства до корупції, недостатній рівень прозорості діяльності органів державної влади й органів місцевого самоврядування.

На думку вчених, цілями антикорупційної політики в Україні має стати зниження рівня корупції та забезпечення захисту прав і законних інтересів громадян, суспільства й держави від загроз, пов'язаних із корупцією, за допомогою виконання таких завдань: запобігання корупційним правопорушенням; створення правового механізму, що перешкоджає підкупу осіб, які мають публічний статус; забезпечення відповідальності за корупційні правопорушення в усіх випадках, прямо передбачених нормативними правовими актами; відшкодування шкоди, заподіяної корупційними правопорушеннями; моніторинг корупційних факторів та ефективності заходів антикорупційної політики; формування антикорупційної суспільної свідомості; сприяння реалізаціі прав громадян та організацій на доступ до інформації про факти корупції й корупціогенні фактори, а також на їх вільне висвітлення в засобах масової інформації; створення стимулів до заміщення державних посад, посад державної й муніципальної служб непідкупними особами [6, с. 242].

На думку Л. Зубкової, основною метою державної політики в галузі протидії корупції $€$ створення ефективної системи запобігання і протидіï корупції, виявлення та подолання ii соціальних передумов і наслідків, викриття корупційних діянь, обов'язкової відповідальності винних. Успішна протидія корупції можлива за умови наявності належного антикорупційного законодавства, ефективного його застосування відповідними органами державної влади та координованості, поінформованості громадськості про здійснення заходів із запобігання і протидіï корупції, взаємодії інститутів громадянського суспільства з органами державної влади у сфері формування й реалізації державної антикорупційної політики, підтримки 
антикорупційних заходів громадянським суспільством [7, с. 34].

Саме на основі ієрархічної системи цілей має формуватися стратегія протидії корупції, яка є важливим структурним елементом антикорупційної політики. За відсутності стратегічних концептуальних ідей і цілей, принципів і пріоритетів, довгострокових загальнодержавних програм, заснованих на глибокому науковому підгрунті, не може бути ніякої антикорупційної політики, а є лише іï видимість. У межах стратегічних напрямів антикорупційної політики розвивається антикорупційна тактика, яка передбачає розроблення конкретних завдань і способів ї виконання [8, с. 180].

Отже, ключовим призначенням антикорупційної державної політики $€$ зменшення корупційних явищ і виявів шляхом формування та реалізації комплексу спеціальних правотворчих, організаційних, правоохоронних заходів. Проте сама категорія «політика» передбачає ширший підхід до процесу визначення системи заходів, необхідних для зменшення корупції [9, с. 31].

Водночас, незважаючи на те що Антикорупційна стратегія належно не виконана, повною мірою не реалізовані іiі цілі, Антикорупційна стратегія визначала пріоритети й окреслювала загальне бачення державної політики у сфері запобігання і протидії корупції, слугувала подальшим орієнтиром атикорупційної політики держави. 3 кінця 2017 року - терміну закінчення Антикорупційої стратегії, у нашій державі фактично відсутня політична антикорупційна воля держави подолання корупції. За відсутності нової Антикорупційної стратегії, відповідно, й уповноважені антикорупційні органи діють незлагоджено, a ї посадові особи, замість того щоб активно вести боротьбу з корупцією, усе частіше стають учасниками конфліктів, у яких задіяні різні політичні сили, що послаблює й без того не досить активну антикорупційну діяльність, водночас «корупційні прояви формуються в соціально неоднорідному просторі, який охоплює політичну, економічну й соціальну сфери сучасного суспільства» [10, с. 17].

Потрібно зазначити, що Закон України «Про запобігання корупції» від 14.10.2014 № 1700-VII визначає правові й організаційні засади функціонування системи запобігання корупції в Україні, зміст і порядок застосування превентивних антикорупційних механізмів, правила щодо усунення наслідків корупційних правопорушень [11].

До визначальних правових ознак, які відрізняють цей орган від інших органів виконавчої влади, варто зарахувати його спеціальний статус; спеціальний порядок формування складу; обмежений термін займання посади члена Національного агентства; способи прийняття владних рішень; специфічні методи роботи $[12$, с. 17].

Згідно зі ст. 11 Закону України «Про запобігання корупції, до повноважень Національного агентства, зокрема, належать проведення аналізу стану запобігання та протидії корупціï в Україні, діяльності державних органів, органів влади Автономної Республіки Крим та органів місцевого самоврядування у сфері запобігання і протидії корупції; статистичних даних, результатів досліджень та іншої інформації стосовно ситуації щодо корупції; розроблення проектів Антикорупційної стратегї та державної програми з іï виконання, здійснення моніторингу, координації й оцінювання ефективності виконання Антикорупційної стратегії; підготовка та подання в установленому законом порядку до Кабінету Міністрів України проекту національної доповіді щодо реалізації засад антикорупційної політики; формування й реалізація антикорупційної політики, розроблення проектів нормативно-правових актів із цих питань.

Указане свідчить, що законодавець саме на Національне агентство поклав обов'язок розробити проект Антикорупційної стратегії та державної програми з їі виконання. Крім того, відповідно до 


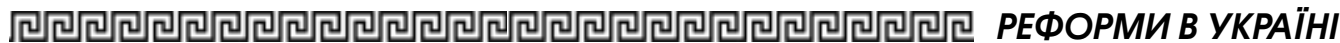

Закону України «Про Кабінет Міністрів України» від 27.02.2014 № 794-VII [13], діяльність Кабінету Міністрів України спрямовується на забезпечення інтересів Українського народу шляхом виконання Конституції та законів України, актів Президента України, а також Програми діяльності Кабінету Міністрів України, схваленої Верховною Радою України, вирішення питань державного управління у сфері економіки та фінансів, соціальної політики, праці й зайнятості, охорони здоров'я, освіти, науки, культури, спорту, туризму, охорони навколишнього природного середовища, екологічної безпеки, природокористування, правової політики, законності, забезпечення прав і свобод людини та громадянина, запобігання і протидії корупції, розв'язання інших завдань внутрішньої й зовнішньої політики, цивільного захисту, національної безпеки та обороноздатності.

Одним зі способів реалізації такого обов'язку держави є розроблення й виконання державних цільових програм боротьби зі злочинністю та корупцією. Як ми вже зазначали, відповідальним за розроблення антикорупційної стратегії в Україні є Національне агентство із запобігання корупції, яке зволікало з розробленням і своєчасним поданням Проекту Закону про Антикорупційну стратегію Кабінету Міністрів України. Оскільки поряд із Верховною Радою України Президент України, Кабінет Міністрів України наділені певними повноваженнями у сфері протидіï корупції, утворюють і законодавчо визначають компетенцію і структуру суб'єктів публічного управління у сфері запобігання корупції [14, с. 231], указані суб'єкти мали спонукати посадових осіб Національного агентства й до своєчасного розроблення та подання на розгляд Кабінету Міністрів України Проекту Закону про Антикорупційну стратегію на 2018-2020 роки.

Розроблений Проект Закону про Антикорупційну стратегію на 2018-2020 роки та Державну програму 3 виконання Антикорупцій- ної стратегії на 2018-2020 роки від 26.04.2018 № 8324 [15] із запізненням подано Кабінетом Міністрів України до Верховної Ради України.

Розглянувши вказаний Проект, Головне науково-консультативне управління Верховної Ради України, зокрема, дійшло висновку, що Проект передбачає величезну кількість заходів, сутність яких полягає в запровадженні певних обмежень, посиленні чинних або запровадженні нових юридичних санкцій, вирішенні тих чи інших організаційних питань. При цьому Проект не містить жодної згадки про заходи, які можна було б розглядати як запровадження стимулів і створення належних умов для доброчесної поведінки потенційних суб'єктів корупційних діянь. Тому проект загалом можна охарактеризувати як такий, що не має комплексного характеру й, по суті, є карально-обмежувальним. 3 огляду на таку незбалансованість, виникає сумнів у можливості ефективної реалізації положень Проекту й досягнення тих цілей, які а ньому декларуються. Проект передбачає прийняття великої кількості нових «антикорупційних» законів, що викликає певний подив, з огляду на те що протягом останніх років парламентом, зокрема, й з ініціативи Уряду вже прийнято чимало законів, які позиціонувалися як антикорупційні. Водночас Проект містить дуже мало приписів про проведення тих чи інших конкретних організаційних, адміністративних заходів, які б спрямовувалися на усунення тих чи інших умов або причин існування корупціогенних чинників. Отже, державі, замість реальної діяльності з протидії корупції, фактично пропонується обмежитися змінюванням законодавства [15].

У подальшому влада України намагалася презентувати Антикорупційну стратегію. Так, на той час заступник керівника Офісу нового Президента України В. Зеленського Р. Рябошапка в липні 2019 року презентував Проект Закону України «Про засади державної антикорупційної політики 


\section{ЮРИАИЧНИЙ ВІСНИК, 2020/1}

в Україні (Антикорупційна стратегія) на 2019-2023 роки», який розроблено не Національним агентством, як це передбачено нормами Закону України «Про запобігання корупції, а Центром політико-правових реформ. Не вдаючись до аналізу неправомірності усунення Національного агентства від розроблення Антикорупційної стратегії, зазначимо, що й до цього часу Антикорупційна стратегія державної антикорупційної політики в Україні відсутня. Сподівання на те, що антикорупційну стратегію ухвалить уже нова Верховна Рада України, що буде слугувати базовим складником успішної протидії корупційним проявам, так до цього часу й не справдилося.

Отже, з урахуванням вищевикладених міркувань можна дійти висновку, що сьогодні в Україні фактично відсутня ефективна стратегія запобігання і протидії корупції, яка б ураховувала гостроту наявної проблеми в державі. У зв'язку із зазначеним варто підкреслити, що основні функції державної антикорупційної політики характеризують їі як соціальне призначення й практичну цінність, яка може проявлятися в різноманітних функціях: ідеологічній, інформаційній, організаційній, виховній, попереджувальній, запобіжній, каральній, що потребує прийняття основного програмного документа в антикорупційній сфері, який би визначив першочергові заходи із запобігання і протидіi корупції в Україні.

y статті досліджено держану політику у сфері запобігання $i$ протидії корупції в Україні. Протягом діяльності нашої держави питання запобігання $i$ протидіï корупціi постійно обговорювалися в державі, до иього прочесу залучалися науковці, фахівці, представники правоохоронних органів. Гостро системні явища корупиії в нашій державі почали проявлятися на початку дев'яностих років минулого століття, що спонукало державу до вжиття певних дій у цььму напря- мі шляхом прийняття відповідних нормативно-правових актів. Першим таким правовим документом, спрямованим на подолання корупціi в Україні, варто вважати Постанову Верховної Ради України «Про невідкладні заходи щодо боротьби з організованою злочинністю $і$ корупцією» від 07.05.1993, якою передбачалоса підготувати й унести на розгляд Верховної Ради України низку проектів законів, спрямованих на протидію корупції й організованій злочинності. Незважаючи на те що цей документ був політико-правовим, він заклав підвалини подальшої правової політики держави у сфері боротьби з корупциї.

Особливо гостро питання боротьби з корупції постало останніми роками, коли вона стала загрозою правам людини та громадянина, верховенству права й демократії, правопорядку й соціальній справедливості, стала перешкодою сталому економічному розвитку суспільства, а також знижуе інвестиційну привабливість України для інвесторів, заважає розвитку бізнесу, руйнує довіру до судової системи та правоохоронної системи. Про це свідчить обговорення цієї проблематики на шпальтах різноманітних засобів масової інформаиіï представниками різних професій, державними посадовиями, оскільки негативне ставлення суспільства до корупиї стало одним із багатьох складників, що спонукають державу вживати різноманітних правових заходів щодо запобігання $i$ протидіi корупиії в державі.

Водночас прийняття значної кількості законодавчих актів і створення відповідних структур у сфері запобігання $i$ протидії корупиіï в державі поки свідчать, що сьогодні ефективна державна політика України у сфері запобігання корупиї ще не вироблена, що потребує подальших наукових пошуків.

Ключові слова: закони, засади, суспільство, право, удосконалення. 


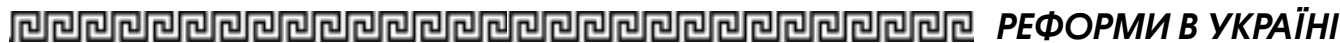

Bashkatova V. State policy on prevention and anti-corruption in Ukraine

The article examines the state policy in the field of prevention and combating corruption in Ukraine. During the activity of our state, the issues of preventing and combating corruption were constantly discussed in the state, scientists, experts and representatives of law enforcement agencies were involved in this process. The acute systemic phenomena of corruption in our country began to manifest themselves in the early nineties of the last century, which prompted the state to take certain actions in this direction, by adopting appropriate legal acts. The first such legal document aimed at combating corruption in Ukraine should be considered the resolution of the Verkhouna Rada of Ukraine "On urgent measures to combat organized crime and corruption" of May 7, 1993, which was supposed to prepare and submit to the Verkhouna Rada of Ukraine a number of draft laws, aimed at combating corruption and organized crime. Despite the fact that this document was political and legal, it laid the foundations for the further legal policy of the state in the fight against corruption.

Particularly acute anti-corruption issues have intensified in recent years, which has become a threat to human and citizen rights, the rule of law and democracy, law and order and social justice, has hindered the sustainable economic development of society, and reduces the investment attractiveness of Ukraine for investors, ruins investors confidence in the judiciary and law enforcement. This is evidenced by the discussion of this issue on the front pages of various mass media by representatives of different professions and public officials, since the negative attitude of society to corruption has become one of the many constituents that compels the state to take various legal measures to prevent and prevent corruption.
At the same time, the adoption of a large number of legislative acts and the establishment of appropriate structures in the field of preventing and combating corruption in the country, while showing that today effective state policy of Ukraine in the field of corruption has not yet been developed, which requires further scientific research.

Key words: laws, principles, society, law, improvements.

\section{Література}

1. Заброда Д.Г. Поняття державної антикорупційної політики. Право $і$ безпека. 2012. № 2 (44). С. 98-104.

2. Новак А.М. Формування основ національної антикорупиійної стратегї в умовах суспільно-політичних трансформацій в Україні. URL: file: / / / C: Lenovo/ Downloads / aplup_2016_1-2_13.pdf C. 92-98.

3. Невмержицький Є.В. Корупиія як соиіально-політичний феномен : автореф. дис. ... докт. політ. наук. Київ, 2009. 34 с.

4. Про засади державної антикорупияійної політики в Украӥні (Антикорупційна стратегія) на 2014-2017 роки : Закон України від 14.10.2014 № 1699-VII.

5. Антикорупиійна стратегія та Державна програма щьодо реалізації засад державної антикорупиійної політики в Украйні (Антикорупиійної стратегії) на 2015-2017 роки, затверджена Постановою Кабінету Міністрів України від 29.04.2015 № 265 .

6. Запобігання ma протидія корупиії : навчальний посібник / авт. кол. : А.М. Михненко (кер. авт. кол.), Р.П. Марчук, А.М. Мудров та ін. ; за ред. проф. А.М. Михненка. Київ : НАДУ, 2010. 360 с.

7. Зубкова Л.А. Сучасний стан $i$ проблеми запобігання корупиії в Україні. Науковий вісник Національної академії внуmpiuнiх справ. 2017. № 3 (104). С. 32-35.

8. Кушнарьов I.В. Стратегія протидіi корупиіi як складова антикорупизйної політики. Право і безпека. 2012. № 5 (47). С. 177-181.

9. Гречанюк P. Національна Антикорупиійна стратегія в системі запобігання корупиіі в Україні. Актуальні проблеми правознавства. 2019. № 3 (19). С. 29-35.

10. Соснін О. Про необхідність використання світового досвіду в боротьбі з корупиією у вітчизняній практиці. Віче. 2014. № 1. С. 14-19. 


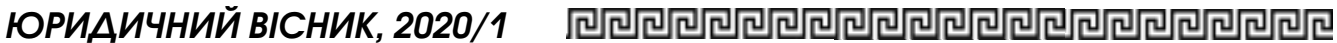

11. Про запобігання корупиіі : Закон України від 14.10. 2014 № 1700-VII. Відомості Верховної Ради України. 2014. № 49. Ст. 2056.

12. Башкатова В.В., Світличний О.П.

Національне агентство з питань запобігання корупиї: адміністративно-правовий статус. Право. Людина. Довкілля. 2019. № 3. С. 103-110.

13. Про Кабінет Міністрів України : Закон України від 27.02.2014 № 794-VII. Відомості Верховної Ради України. 2014. № 13. Cm. 222 .
14. Світличний О., Кадегроб А. Суб’єкти публічного управління у сфері запобігання порушенням, пов'язаним з корупиією. Підприємниитво, господарство і право. 2020. № 2. C. 230-234.

15. Проект Закону про Антикорупиійну стратегію на 2018-2020 роки від 26.04 .2018 № 8324 : Висновок Головного науково-консультативного управління Верховної Ради України від 11.05.2018. URL: http: / / w1.c1.rada.gov.ua/pls / zweb2 / webproc4_1? pf3511=63942. 